\title{
Pengaruh Penambahan Surfaktan pada Fermentasi Tandan Kosong Kelapa Sawit dengan Praperlakuan Uap Air Panas Bertekanan dengan Katalis Asam Maleat
}

\author{
Sita Heris Anita ${ }^{1 *}$, Devi Nury Ashrianis ${ }^{2}$, Widya Fatriasari ${ }^{1}$ \\ ${ }^{1}$ Pusat Penelitian Biomaterial, Lembaga Ilmu Pengetahuan Indonesia, Bogor, Jawa Barat, Indonesia \\ ${ }_{2}^{2}$ Diploma Analis Kimia, Institut Pertanian Bogor, Bogor, Jawa Barat, Indonesia
}

\begin{abstract}
Corresponding author:
Sita Heris Anita

sita.heris@biomaterial.lipi.go.id

Received: February 2021

Accepted: March 2021

Published: March 2021

(C) Sita Heris Anita et al. This is an open-access article distributed under the terms of the Creative Commons Attribution License, which permits unrestricted use, distribution, and reproduction in any medium, provided the original author and source are credited.
\end{abstract}

\begin{abstract}
Oil palm empty fruit bunch (OPEFB) has high potency to be converted into second generation bioethanol production. OPEFB pretreated liquid hot water (LHW) assisted maleic acid (MA) pretreatment was used as substrate in simultaneous saccharification fermentation (SSF). This pretreatment was conducted at $180{ }^{\circ} \mathrm{C}$ for $70 \mathrm{~min}$ by using $1.5 \%(\mathrm{w} / \mathrm{v}) \mathrm{MA}$ acid concentration with material and liquid ratio of 1:14. Subsequently, the pretreated samples were fermented by addition of surfactant, polyethylene glycol (PEG) 4000 and amphiphilic lignin derivatives (A-LD) using Kluyveromyces marxianus InaCC Y119 yeast at temperature of $38{ }^{\circ} \mathrm{C}$ for $89 \mathrm{~h}$. Before SSF, pretreated OPEFB was pre hydrolyzed by cellulase enzyme with enzyme loading 30 FPU/g at $50{ }^{\circ} \mathrm{C}$ for $3 \mathrm{~h}$. Fermentation filtrate was taken at $0,24,48,72$, dan 89 $\mathrm{h}$ as much as $1.5 \mathrm{~mL}$ for reducing sugar and ethanol content determination. The surfactant addition can enhance reducing sugar and also ethanol content compared to control. The highest ethanol content of $1.251 \mathrm{~g} / \mathrm{L}$ was found at fermentation of OPEFB pretreated MA with PEG 4000 surfactant at $89 \mathrm{~h}$.
\end{abstract}

Keywords: maleic acid, SSF, lignocellulose, LHW, biosurfactant

\section{Pendahuluan}

Penggunaan biomassa berlignoselulosa dari bahan non pangan dapat meminimalisasi kompetisi penggunaan bahan pangan sebagai sumber pangan atau energi [1]. Biomassa berlignoselulosa merupakan bahan baku nonpangan yang berasal dari tanaman yang mengandung komponen utama selulosa, hemiselulosa, dan lignin. Salah satu biomassa lignoselulosa yang berpotensi untuk dimanfaatkan sebagai sumber bioetanol adalah

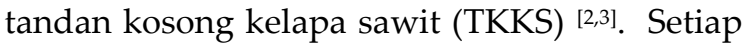
ton produksi minyak kelapa sawit menghasilkan TKKS sebesar $22 \%$ atau $220 \mathrm{~kg}{ }^{[4]}$.

Proses pembuatan bioetanol generasi kedua menggunakan biomassa lignoselulosa melalui tiga tahapan, yaitu praperlakuan, hidrolisis, dan fermentasi. Tahap praperlakuan ditujukan untuk membuka struktur kompleks biomassa lignoselulosa sehingga dapat mempermudah proses pemecahan polimer selulosa menjadi glukosa pada tahap hidrolisis [5]. Salah satu praperlakuan fisik-kimia yang cukup menjanjikan adalah praperlakuan uap air panas bertekanan menggunakan reaktor bertekanan untuk mempertahankan air tetap dalam fase cair pada suhu tinggi. Praperlakuan uap air panas bertekanan dapat dilakukan tanpa penambahan bahan kimia selama proses [6].

Praperlakuan uap air panas bertekanan dengan katalis asam maleat dan oksalat pada TKKS telah dilaporkan sebelumnya [2]. Praperlakuan uap air panas bertekanan dengan katalis asam 
maleat menunjukkan rendemen gula yang lebih tinggi dibandingkan asam oksalat. Meskipun demikian, pada penelitian tersebut belum diperoleh informasi kadar bioetanol yang dihasilkan setelah praperlakuan uap air panas bertekanan-asam maleat. Oleh karena itu penelitian ini dilakukan untuk memberikan informasi terkait produksi bioetanol melalui metode Sakarifikasi dan Fermentasi Serentak (SSF). Salah satu khamir yang berpotensi untuk SSF adalah Kluyveromyces marxianus. Penggunaan khamir tersebut pada fermentasi TKKS dengan praperlakuan gelombang mikroasam oksalat menghasilkan rendemen etanol yang lebih tinggi dibandingkan dengan khamir Saccharomyces cereviceae [7].

Penambahan surfaktan diketahui mampu meningkatkan kinerja proses hidrolisis dan fermentasi. Hal tersebut karena surfaktan mampu menurunkan tegangan permukaan sehingga meningkatkan kinerja enzim [8]. Beberapa surfaktan komersial baik ionik dan non ionik seperti Trixton $X$, tween, PEG (polyethylene glycol) sering ditambahkan pada hidrolisis enzimatis [9,10,11]. Selain surfaktan komersial, biosurfaktan berbasis lignin, Amphipilic Lignin Derivatives (A-LD), juga telah dikembangkan dan ditambahkan dalam proses fermentasi pulp kraft yang tidak diputihkan dari bagas sorgum [12]. Penambahan 5\% (b/v) A-LD dari lignin kraft Acacia mangium pada hidrolisis enzimatis pulp kraft bagas sorgum juga dilaporkan mampu meningkatkan rendemen gula pereduksi ${ }^{[3]}$. Pada penelitian ini dievaluasi pengaruh penambahan A-LD ataupun surfaktan komersial seperti PEG 4000 pada proses SSF dengan K.marxianus pulp TKKS dengan praperlakuan uap air panas bertekanan dengan katalis asam maleat.

\section{Metode Penelitian}

\section{Bahan kimia}

Bahan yang digunakan pada penelitian adalah serbuk tandan kosong kelapa sawit (TKKS) berukuran 40-60 mesh yang diperoleh dari Cibadak, Sukabumi, Jawa Barat, Indonesia pada tahun 2019, asam maleat (Wako), pepton (Merck), glukosa (Merck), yeast extract (Merck), enzim celluclast Trichoderma reesei ATCC 26921 (Sigma Aldrich) dengan aktivitas enzim $42.3 \mathrm{~mL}$ sejumlah $30 \mathrm{FPU} / \mathrm{g}$, bufer sitrat $0.05 \mathrm{M}$ (pH 4.8), asam 3, 5-dinitrosalisilat (Sigma Aldrich), PEG 4000 dan Amphipilic Lignin Derivatives (A-LD) sebanyak $15 \mathrm{mg} / \mathrm{mL}$ yang disiapkan berdasarkan Fatriasari dkk.[3]. Mikroorganisme yang digunakan yaitu khamir Kluyveromyces marxianus InaCC Y119.

\section{Peralatan}

Alat-alat yang digunakan dalam penelitian adalah reaktor uap air panas bertekanan, timbangan analitik, inkubator pengocok (BioShaker BR-300), hot plate, autoklaf, peralatan gelas, spektrofotometer UV-VIS (Szimadzu UV 1800), dan kromatografi gas (GC-2010 Plus Simadzu).

\section{Prosedur penelitian}

Praperlakuan uap air panas bertekanan dengan katalis asam maleat

Proses praperlakuan mengacu pada metode praperlakuan Sari dkk. [2]. Serbuk TKKS berukuran 40-60 mesh sebanyak $5 \mathrm{~g}$ ditambahkan $70 \mathrm{~mL}$ larutan asam maleat konsentrasi $1.5 \%(\mathrm{~b} / \mathrm{v})$ dengan perbandingan bahan dan larutan sebesar 1:14 (b/v). Praperlakuan dengan air digunakan sebagai kontrol dengan perbandingan yang sama. Campuran serbuk TKKS dengan larutan tersebut kemudian diberikan praperlakuan dengan reaktor uap air panas bertekanan pada suhu $180{ }^{\circ} \mathrm{C}$ selama 70 menit disertai dengan pengadukan. Selanjutnya campuran disaring menggunakan pompa vakum. Fraksi padat yang sudah dipisahkan, kemudian dinetralkan dengan air distilasi hingga mencapai $\mathrm{pH}$ 5-7. Fraksi padat netral kemudian disimpan pada suhu $4{ }^{\circ} \mathrm{C}$ sebelum digunakan.

\section{Persiapan inokulum khamir Kluyveromyces marxianus InaCC Y119}

Sebanyak 1-2 ose khamir Kluyveromyces marxianus InaCC Y119 diinokulasikan ke dalam $500 \mathrm{~mL}$ Erlenmeyer yang berisi $100 \mathrm{~mL}$ media YPG (Yeast Extract Peptone Glucose) dengan komposisi $10 \mathrm{~g} / \mathrm{L}$ yeast extract, $20 \mathrm{~g} / \mathrm{L}$ pepton dan 
50 g/L glukosa. Campuran inokulum kemudian diinkubasi pada suhu $30{ }^{\circ} \mathrm{C}$ dalam inkubator pengocok dengan kecepatan 120 rpm selama 1620 jam. Densitas sel kemudian diukur menggunakan spektrofotometer pada panjang gelombang $600 \mathrm{~nm}$ dengan nilai sebesar 0.800 . Volume inokulum yang digunakan untuk fermentasi ditentukan berdasarkan persamaan (1).

Total vi $=\frac{\text { Total } \mathrm{v} \times 0.5}{\mathrm{OD} \mathrm{i}} \times(\mathrm{je}+1)$

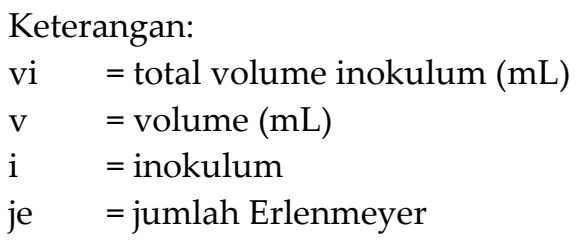

Sebelum digunakan inokulum disentrifugasi pada 10,000 rpm, $4{ }^{\circ} \mathrm{C}$ selama 10 menit kemudian supernatan didekantasi. Padatan sel kemudian diresuspensi menggunakan air distilasi steril. Suspensi sel digunakan sebagai inokulum pada proses fermentasi ${ }^{[13]}$.

\section{Sakarifikasi dan fermentasi serentak (SSF)}

Proses SSF dilakukan sesuai dengan metode NREL ${ }^{[13]}$ yang dimodifikasi pada berat sampel.
Sampel yang digunakan untuk proses SSF terdiri dari pulp TKKS hasil praperlakuan uap air panas bertekanan-asam maleat (PM), uap air panas bertekanan-air (PA) dan TKKS tanpa praperlakuan (K). Detail kondisi SSF pada sampel tersebut mengacu pada Tabel 1. Sampel dengan berat tertentu dimasukkan ke dalam Erlenmeyer $250 \mathrm{~mL}$ kemudian disterilisasi menggunakan autoklaf selama 15 menit. Proses prehidrolisis dilakukan dengan menambahkan $0.05 \mathrm{M}$ bufer sitrat ( $\mathrm{pH}$ 4.8) dan enzim selulase kemudian diinkubasi dalam inkubator pengocok pada suhu $50{ }^{\circ} \mathrm{C}$ berkecepatan 150 rpm selama 3 jam. Sampel hasil prehidrolisis ditambahkan media YP (3 mL) dan 10\% (v/v) inokulum khamir. Erlenmeyer berisi campuran sampel ditutup dengan leher angsa dan diinkubasi dalam inkubator pengocok bersuhu $38{ }^{\circ} \mathrm{C}$ berkecepatan $150 \mathrm{rpm}$ selama 89 jam. Pengambilan filtrat sampel untuk pengujian gula pereduksi dan konsentrasi etanol sebanyak $1.5 \mathrm{~mL}$ dilakukan pada $0,24,48$, 72, dan 89 jam selama proses inkubasi.

\section{Analisis gula pereduksi dan konsentrasi etanol}

Sampel setelah proses SSF kemudian disentrifugasi pada 10,000 rpm selama 10 menit. Supernatan kemudian digunakan untuk analisis gula pereduksi dan konsentrasi etanol.

Tabel 1. Eksperimen SSF

\begin{tabular}{lccccccc}
\hline Jenis sampel & $\begin{array}{c}\text { Berat } \\
\text { sampel }(\mathrm{g})\end{array}$ & $\begin{array}{c}\text { Enzim } \\
\text { selulase } \\
(\mathbf{m L}), \mathbf{3 0} \\
\text { FPU/g }\end{array}$ & $\begin{array}{c}\text { Bufer } \\
\text { sitrat }(\mathbf{m L})\end{array}$ & $\begin{array}{c}\text { Media YP } \\
(\mathbf{m L})\end{array}$ & $\begin{array}{c}\text { Inokulum } \\
\text { khamir } \\
(\mathbf{m L})\end{array}$ & $\begin{array}{c}\text { Surfaktan } \\
(\mathbf{m L}), \mathbf{4} \% \\
\text { BKO } \\
\text { substrat }\end{array}$ & $\begin{array}{c}\text { Air yang } \\
\text { ditambah- } \\
\text { kan }(\mathbf{m L})\end{array}$ \\
\hline $\begin{array}{l}\text { Praperlakuan } \\
\text { dengan asam } \\
\text { maleat (PM) }\end{array}$ & 8.42 & 1.90 & 2.50 & 3.00 & 3.00 & 7.20 & 3.98 \\
$\begin{array}{l}\text { Praperlakuan } \\
\text { dengan air } \\
\text { (PA) }\end{array}$ & 10.21 & 1.90 & 2.50 & 3.00 & 3.00 & 7.12 & 2.27 \\
$\begin{array}{l}\text { Tanpa } \\
\text { praperlakuan } \\
\text { (K) }\end{array}$ & 3.07 & 2.00 & 2.50 & 3.00 & 3.00 & 7.44 & 8.99 \\
\hline
\end{tabular}


Analisis gula pereduksi menggunakan DNS berdasarkan metode Miller [14] dan diukur menggunakan UV-Vis spektrofotometer pada panjang gelombang $540 \mathrm{~nm}$. Sedangkan etanol dianalisis menggunakan gas kromatografi (GC2010 Plus Simadzu). Kolom yang digunakan RTX-WAX dengan suhu injektor $200{ }^{\circ} \mathrm{C}$ dan detektor $210^{\circ} \mathrm{C}$. Suhu awal kolom sebesar $35^{\circ} \mathrm{C}$ ditahan selama 1 menit kemudian dinaikkan sampai suhu $80^{\circ} \mathrm{C}$ ditahan selama 5 menit. Gas pembawa (fase gerak) yang digunakan ialah gas nitrogen dan gas hidrogen. Volume sampel yang diinjeksikan sebanyak $1 \mu \mathrm{L}$ dengan total flow $24.65 \mathrm{~mL} /$ menit dan split rasio 10. Konsentrasi etanol dihitung berdasarkan persamaan (2) [15].

Kons. etanol $=\%$ etanol $\times 10 \times 0.789$

Keterangan:

Kons. etanol = konsentrasi etanol $(\mathrm{g} / \mathrm{L})$

$\%$ etanol $=$ kadar etanol $(\mathrm{v} / \mathrm{v})$

\section{Hasil dan Diskusi}

\section{Pengaruh praperlakuan terhadap konsentrasi} gula pereduksi awal

Praperlakuan pada TKKS memengaruhi konsentrasi gula pereduksi awal yang dihasilkan setelah proses prehidrolisis. Tahap prehidrolisis secara enzimatik bertujuan menghomogenkan sampel dan meningkatkan konsentrasi hidrolisat glukosa untuk fermentasi melalui hidrolisis padatan sampel pada suhu tinggi [16] sehingga etanol yang dihasilkan lebih tinggi. Prehidrolisis pada TKKS dengan praperlakuan asam maleat berbantu gelombang mikro diketahui dapat meningkatkan rendemen etanol pada proses SSF [3]. Konsentrasi gula pereduksi awal yang terbentuk setelah proses prehidrolisis ditunjukkan pada Gambar 1.

Konsentrasi gula pereduksi awal yang terbentuk pada filtrat sampel PM dan PA lebih tinggi jika dibandingkan dengan kontrol (K). Tingginya konsentrasi gula pereduksi pada PM mengindikasikan struktur sampel PM lebih mudah didegradasi enzim karena telah terdegradasinya komponen penyusun TKKS seperti lignin dan hemiselulosa akibat proses praperlakuan. Konsentrasi gula pereduksi yang terbentuk menandakan bahwa selulosa telah dihidrolisis menjadi glukosa oleh enzim selulase. Jumlah selulosa yang dapat dihidrolisis menjadi glukosa dipengaruhi oleh kemampuan enzim dalam menjangkau selulosa dalam struktur kompleks lignoselulosa. Menurut Hidayat [17], asam dapat melarutkan sebagian hemiselulosa sehingga selulosa dapat lebih mudah dijangkau oleh enzim ketika proses hidrolisis. Hal itu mengakibatkan konsentrasi gula pereduksi lebih tinggi pada sampel yang telah diberikan praperlakuan jika dibandingkan dengan kontrol.

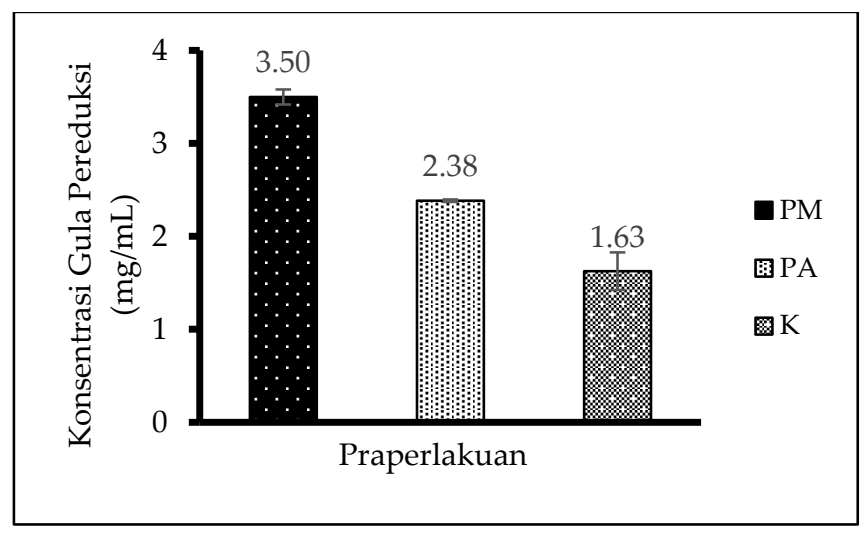

Gambar 1. Konsentrasi gula pereduksi awal pada filtrat hasil prehidrolisis TKKS praperlakuan uap air panas bertekanan-asam maleat (PM), praperlakuan uap air panas bertekanan-air (PA), dan kontrol (K). 
Pengaruh penambahan surfaktan terhadap konsentrasi gula pereduksi dan etanol

Penambahan surfaktan pada proses SSF bertujuan untuk meningkatkan konsentrasi gula pereduksi pada saat proses hidrolisis sehingga secara tidak langsung dapat memengaruhi produksi etanol saat fermentasi. Pada penelitian ini digunakan surfaktan PEG 4000 dan A-LD pada proses SSF. Kedua surfaktan tersebut masuk ke dalam jenis surfaktan non ionik. PEG 4000 merupakan salah satu jenis surfaktan komersial yang telah banyak digunakan dalam proses hidrolisis biomassa. Polietilen dan turunannya telah digunakan sebagai molekul hidrofilik karena sifatnya yang dapat didegradasi dengan mudah di alam dengan tingkat toksisitas rendah ${ }^{[18]}$. Beberapa penelitian melaporkan bahwa surfaktan non ionik bersifat lebih efektif dalam meningkatkan laju hidrolisis selulosa oleh enzim dibandingkan surfaktan jenis lain [19-22]. Hal ini karena A -LD merupakan polimer larut air yang dapat mencegah penyerapan enzim non reproduktif dalam proses hidrolisis enzimatis [23]. Penambahan surfaktan A-LD dalam fermentasi pulp kraft bagas sorgum dilaporkan dapat meningkatkan produksi etanol dan mempersingkat waktu fermentasi ${ }^{[18]}$.

Konsentrasi gula pereduksi yang dihasilkan pada variasi penambahan surfaktan ditunjukkan pada Gambar 2. Konsentrasi gula pereduksi pada t0 fermentasi menunjukkan bahwa pada perlakuan tanpa penambahan surfaktan konsentrasi gula pada semua perlakuan (PM, PA, K) memiliki konsentrasi yang sama seperti saat selesai proses prehidrolisis. Sedangkan pada t0 fermentasi dengan penambahan surfaktan (A-LD maupun PEG) menunjukkan nilai yang lebih tinggi jika dibandingkan dengan konsentrasi gula pereduksi setelah proses prehidrolisis. Penambahan surfaktan kemungkinan dapat meningkatkan gula pereduksi yang larut di dalam sistem fermentasi sehingga konsentrasi gula pereduksi awal menjadi lebih tinggi jika dibandingkan tanpa penambahan surfaktan. Surfaktan dapat mengurangi ikatan non reproduktif antara enzim dan selulosa dan interaksi hidrofobik non spesifik antara enzim dan lignin dalam biomassa [24]. Surfaktan dapat mengubah struktur alami substrat baik dengan cara memperluas permukaan kontak antara enzim dengan selulosa atau dengan cara menghilangkan komponen lignin yang berperan sebagai penghambat [19]. Penambahan surfaktan dapat mengurangi hambatan ikatan enzim dengan selulosa sehingga gula-gula sederhana hasil prehidrolisis yang terperangkap di dalam komponen tersebut dapat lepas dan larut di dalam cairan fermentasi. Penambahan surfaktan tween 80 pada konsentrasi $0.4 \%$ dilaporkan juga dapat meningkatkan gula yang larut dari $8.14 \mathrm{~g}$ menjadi $10.15 \mathrm{~g}$ per $100 \mathrm{~g}$ substrat [25].

Konsentrasi gula pereduksi yang dihasilkan selama fermentasi pada perlakuan penambahan surfaktan pada sampel dengan praperlakuan asam maleat, secara umum menunjukkan hasil yang lebih tinggi dibandingkan dengan konsentrasi gula pereduksi tanpa penambahan surfaktan. Liu dkk. [26] melaporkan bahwa penambahan surfaktan non ionik seperti rhamnolipid dan tween 80 meningkatkan laju produksi gula pereduksi. Penambahan tween 20 pada proses hidrolisis batang sawit juga menghasilkan gula pereduksi yang lebih tinggi jika dibandingkan tanpa surfaktan [11]. Penambahan surfaktan memengaruhi kinerja enzim saat proses hidrolisis. Surfaktan dapat mempercepat reaksi hidrolisis dengan meningkatkan kinerja enzim dalam mengubah selulosa menjadi glukosa. Peningkatan kinerja enzim oleh surfaktan karena berkurangnya interaksi antara lignin yang ada dalam biomassa dengan sisi aktif enzim [12]. Selain itu surfaktan juga dapat menurunkan tegangan permukaan sehingga memperbaiki kinerja enzim dan

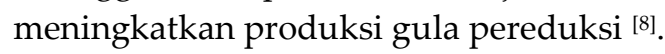

Penambahan surfaktan A-LD pada sampel dengan praperlakuan asam maleat pada proses SSF mengakibatkan konsentrasi gula pereduksi terus meningkat selama proses fermentasi selama 89 jam (Gambar 2b). Sedangkan penambahan surfaktan PEG 4000 menghasilkan konsentrasi gula pereduksi tertinggi pada 24 jam inkubasi kemudian terus menurun seiring lamanya waktu fermentasi (Gambar 2c). Penambahan surfaktan pada proses SSF dapat 
meningkatkan laju hidrolisis sehingga menghasilkan gula pereduksi yang lebih tinggi dibandingkan kontrol. Akan tetapi laju penggunaan gula tersebut oleh khamir untuk diubah menjadi etanol terjadi lebih lambat. Proses konversi gula pada sistem SSF dengan penambahan surfaktan A-LD terjadi lebih lambat jika dibandingkan dengan penambahan surfaktan PEG 4000. Hal tersebut ditunjukkan dari hasil konsentrasi gula yang masih tinggi pada waktu inkubasi 89 jam (Gambar 2b). Konsentrasi gula pereduksi tertinggi yang dihasilkan dengan penambahan kedua surfaktan tersebut adalah sekitar 7.52-7.54 $\mathrm{mg} / \mathrm{mL}$ dengan waktu optimum yang berbeda.
Perbedaan tersebut dapat disebabkan oleh kecepatan sel khamir dalam menggunakan gula yang dihasilkan untuk dikonversi menjadi etanol. Perbedaan surfaktan yang digunakan berpengaruh terhadap penggunaan gula pereduksi oleh khamir. Efek stimulasi surfaktan PEG 4000 lebih baik jika dibandingkan dengan A-LD dalam peningkatan laju pemanfaatan gula pereduksi oleh khamir dan PEG 4000 kemungkinan tidak menghambat pertumbuhan sel khamir selama proses fermentasi. Penggunaan tween 80 juga dilaporkan lebih baik dibandingkan dengan rhamnolipid dalam hal pemanfaatan gula pereduksi oleh khamir [26].
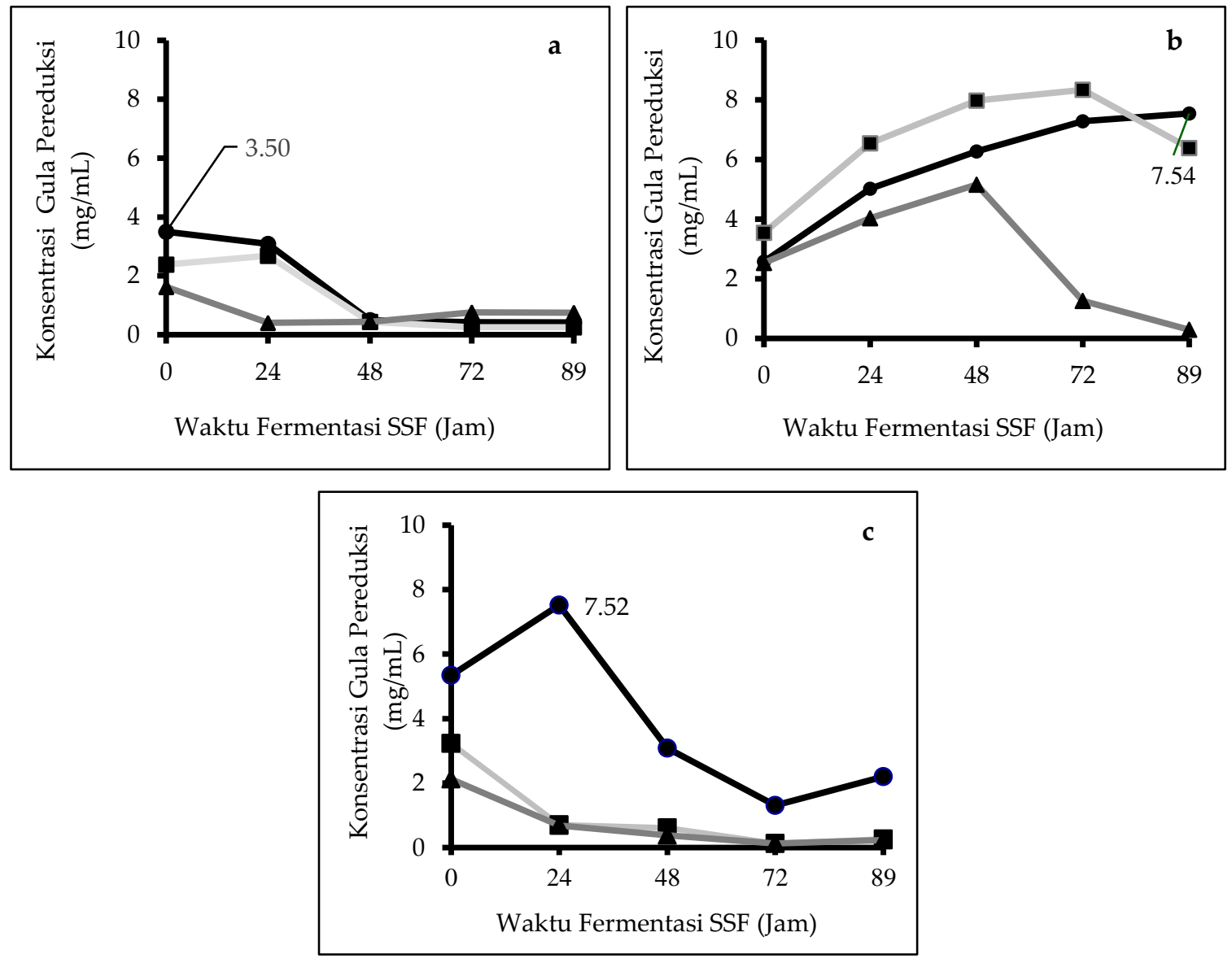

Gambar 2. Konsentrasi gula pereduksi filtrat sampel hasil praperlakuan dengan asam maleat (O), praperlakuan dengan air $(\mathbf{Q})$ dan kontrol $(\boldsymbol{\Delta})$ pada kondisi a) tanpa penambahan surfaktan, b) penambahan surfaktan A-LD, c) penambahan surfaktan PEG 4000). 
Produktivitas etanol oleh khamir K. marxianus pada berbagai perlakuan penambahan surfaktan dapat dilihat pada Gambar 3. Variasi perlakuan penambahan surfaktan memengaruhi kadar etanol yang dihasilkan. Kadar etanol tertinggi yang dihasilkan pada sampel tanpa penambahan surfaktan, secara umum dicapai seluruh sampel pada waktu fermentasi 48 jam (Gambar 3a). Hasil tersebut sesuai dengan kadar gula pereduksi seluruh sampel yang menunjukkan nilai paling rendah pada waktu fermentasi 48 jam (Gambar 3a). Hal tersebut menandakan bahwa pada waktu 48 jam, gula pada sampel terkonversi menjadi etanol oleh khamir. Penambahan surfaktan ALD maupun PEG 4000 memengaruhi kadar etanol yang dihasilkan oleh khamir K. marxianus (Gambar 3b dan 3c). Kadar etanol tertinggi pada perlakuan penambahan surfaktan A-LD dihasilkan oleh sampel PM sebesar $0.537 \mathrm{~g} / \mathrm{L}$ saat waktu fermentasi 48 jam (Gambar 3b). Kadar etanol yang dihasilkan pada penambahan surfaktan A-LD lebih rendah jika dibandingkan dengan kadar etanol tanpa penambahan surfaktan (0.832 g/L). Sedangkan penambahan surfaktan PEG 4000 menghasilkan kadar etanol $1.211 \mathrm{~g} / \mathrm{L}$ pada waktu 89 jam fermentasi. Kadar etanol yang dihasilkan pada penambahan surfaktan PEG 4000 yaitu 45.6\% lebih tinggi jika dibandingkan tanpa penambahan surfaktan namun membutuhkan waktu fermentasi yang lebih lama.
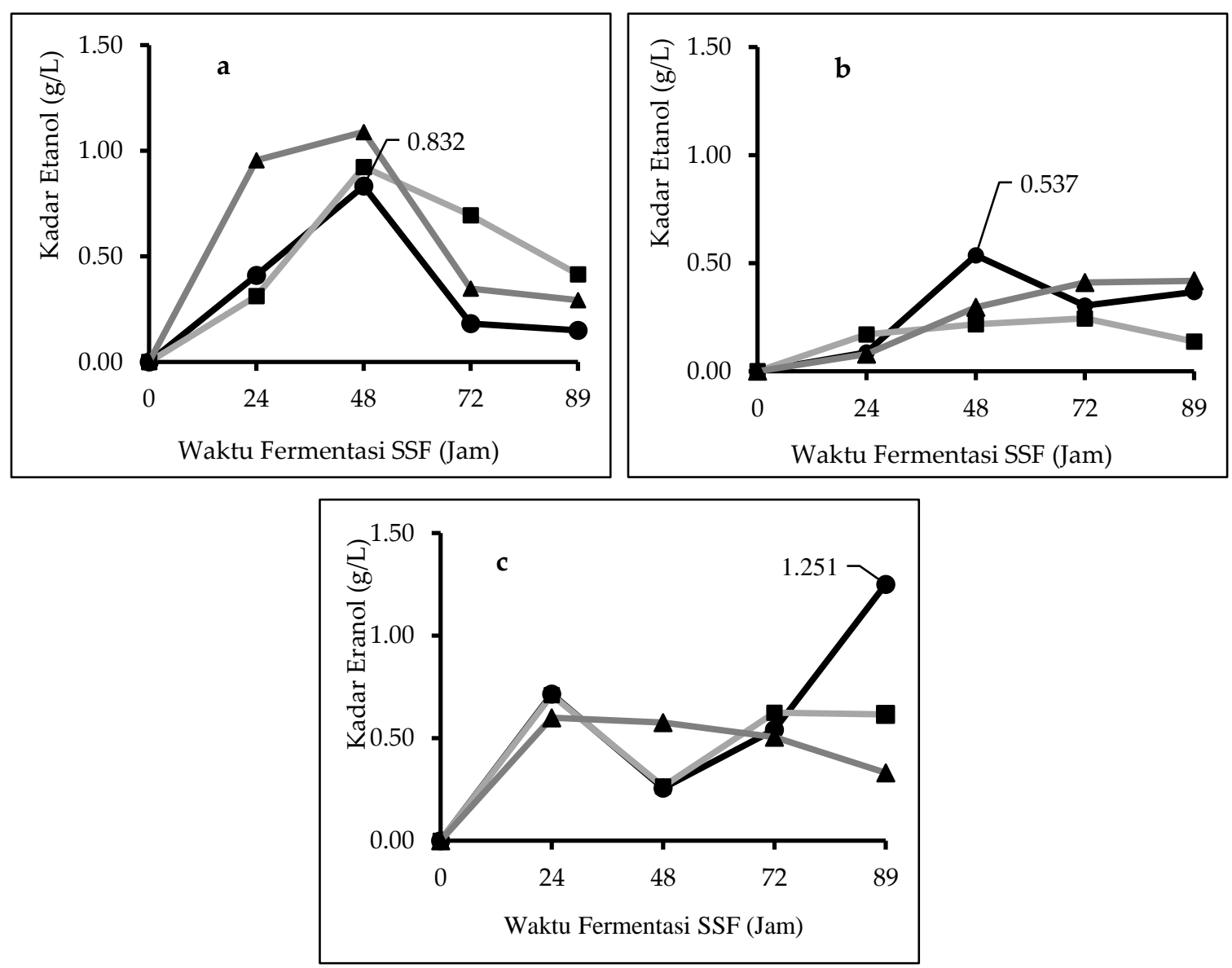

Gambar 3. Kadar etanol filtrat sampel hasil praperlakuan dengan asam maleat (O), praperlakuan dengan air $(\mathbf{D})$ dan kontrol $(\boldsymbol{\Delta})$ pada kondisi a) tanpa penambahan surfaktan, b) penambahan surfaktan A-LD, c) penambahan surfaktan PEG 4000. 
Liu dkk. [26] melaporkan bahwa konsentrasi etanol dengan penambahan surfaktan rhamnolipid dan tween 80 meningkat berturutturut sebesar $12.2 \%$ dan $21.3 \%$ dibandingkan dengan kontrol. Penelitian lain melaporkan bahwa produksi etanol oleh Saccharomyces cerevisiae HI-7 lebih tinggi $10-20 \%$ dengan penambahan surfaktan tween 20 dan tween 80 dibandingkan dengan kontrol dan terhambat dengan penambahan surfaktan Triton-X [27]. Pada penelitian penambahan surfaktan A-LD pada proses SSF dengan substrat pulp kraft bagas sorgum memberikan pengaruh positif terhadap etanol yang dihasilkan yaitu sebesar $4.91 \mathrm{~g} / \mathrm{L}$ pada waktu fermentasi 24 jam [18]. Namun pada penelitian ini, penggunaan surfaktan A-LD pada proses SSF dengan substrat TKKS hanya menghasilkan etanol sebesar $0.537 \mathrm{~g} / \mathrm{L}$. Hal ini dapat disebabkan karena kadar lignin bagas sorghum sangat rendah dibandingkan dengan TKKS yang digunakan pada penelitian ini (data tidak dipublikasi).

Penambahan surfaktan terhadap produksi etanol sangat dipengaruhi oleh jenis substrat atau bahan baku, jenis enzim, dan mikroorganisme yang digunakan [26]. Surfaktan dapat meningkatkan permeabilitas membran sel yang secara tidak langsung berperan dalam peningkatan produksi etanol. Akan tetapi sifat permeabilitas membran sel sangat dipengaruhi oleh komponen penyusun sel membran seperti komposisi sterol. Hal tersebut menyebabkan pengaruh dari penambahan surfaktan pada setiap mikroorganisme berbeda-beda. Surfaktan dapat memfasilitasi pergerakan molekul melintasi membran sel dengan cara mengurangi tegangan permukaan, melarutkan komponen membran yang tidak larut dalam air, dan mengubah konformasi makromolekul seperti protein yang terdapat pada membran sel. Hal tersebut menyebabkan perubahan permeabilitas membran sehingga memengaruhi sistem transport membran baik untuk transport molekul glukosa maupun etanol yang dihasilkan sel [27, 28].

\section{Kesimpulan}

Penambahan surfaktan dapat meningkatkan konsentrasi gula pereduksi dan kadar etanol. Perbedaan jenis surfaktan berpengaruh terhadap kinerja enzim dan khamir dalam memproduksi gula pereduksi dan etanol. Surfaktan PEG 4000 lebih berperan dalam meningkatkan kadar etanol yang dihasilkan dibandingkan dengan A-LD. Kadar etanol tertinggi diperoleh sebesar $1.251 \mathrm{~g} / \mathrm{L}$ pada kondisi penambahan surfaktan PEG 4000 dengan sampel hasil praperlakuan uap air panas bertekanan-asam maleat (PM) dengan waktu fermentasi 89 jam. Kadar etanol yang dihasilkan pada penambahan surfaktan PEG 4000 yaitu $45.6 \%$ lebih tinggi jika dibandingkan tanpa penambahan surfaktan.

\section{Ucapan Terima Kasih}

Penelitian ini merupakan bagian dari DIPA Pusat Penelitian Biomaterial dan Kegiatan Unggulan LIPI - Lembaga Ilmu Pengetahuan Indonesia Tahun Anggaran 2016-2017. Penelitian ini didukung oleh fasilitas riset, dan dukungan ilmiah serta teknis dari Laboratorium Bioproduk Terintegrasi di Lembaga Ilmu Pengetahuan Indonesia.

\section{Daftar Pustaka}

1. Novia, Windarti, A, \& Rosmawati, Pembuatan bioetanol dari jerami padi dengan metode ozonolisis - simultaneous saccharification and fermentation (SSF). JTK, 20(3): 38-48 (2014).

2. Sari, F.P, Sholihat, N.N., Anita, S.H, Fitria, \& Hermiati, E., Peningkatan produksi gula pereduksi dari tandan kosong kelapa sawit dengan praperlakuan asam organik pada reaktor bertekanan. Reaktor, 16(4): 199-206 (2016).

3. Fatriasari, W., Raniya, R., Oktaviani, M., \& Hermiati, E., The improvement of sugar and bioethanol production of oil palm empty fruit bunches (Elaeis guineensis Jacq) through microwave-assisted maleic 
acid pretreatment. Bioresour., 13(2): 4378 4403 (2018).

4. Erivianto, D., Abhi, P.B., \& Notosudjono, D., Penggunaan limbah kelapa sawit untuk menghasilkan tenaga listrik pada existing boiler. Saintech., 26(2): 85-95 (2016).

5. Hermiati, E., Mangunwidjaja, D., Sunarti, T.C., Suparno, O., \& Prasetya, B., Pemanfaatan biomassa lignoselulosa ampas tebu untuk produksi bioetanol. J. Litbang Pertan., 29(4): 121-130 (2010).

6. Yu, Q., Zhuang, X., Lv, S., He, M., Zhang, Y., Yuan, Z ., Qi, W., Wang, Q., Wang, W., \& Tan, X., Liquid hot water pretreatment of sugarcane bagasse and its comparison with chemical pretreatment methods for the sugar recovery and structural changes. Bioresour.Technol., 129: 592-598 (2013).

7. Anita, S.H, Oktaviani, M., \& Hermiati, E., Bioethanol production from pretreated oil palm empty fruit bunches of SHF and SSF system by using ethanologenic yeast. Jurnal Lignocellul. Technol., (2018).

8. Li, J, Li, S., Fan, C., \& Yan, Z., The mechanism of poly (ethylene glycol) 4000 effect on enzymatic hydrolysis of lignocellulose. Coloids Surf. B., 89: 203-210 (2012).

9. Börjesson, J, Engqvist, M., Sipos, B., \& Tjerneld, F., Effect of poly (ethylene glycol) on enzymatic hydrolysis and adsorption of cellulase enzymes to pretreated lignocellulose. Enzym. Microb. Technol., 41: 186-195 (2007).

10. Zhou, Y.H., Chen, F., Qi, X., Zhao, \& Liu, D., Non-ionic surfactants do not consistently improve the enzymatic hydrolysis of pure cellulose. Bioresour. Technol., 18: 136-140 (2015).

11. Winarni, I, Komarayati, S., \& Bardant, T. B., Pembuatan bioetanol secara enzimatis dari limbah batang sawit (Elaeis guineensis) dengan penambahan surfaktan. J. Penelit. Has. Hutan, 34(2): 127-135 (2016).

12. Cheng, N, Koda, K., Tamai, Y., Yamamoto, Y., Takasuka, T.E., \& Uraki, Y., Optimization of simultaneous saccharification and fermentation conditions with amphipilic lignin derivatives for concentrated bioethanol production. Bioresour. Technol., 232: 126-132 (2017).

13. Dowe, N. \& Mcmillan, J., SSF experimental protocols - lignocellulosic biomass hydrolysis and fermentation laboratory analytical procedure (LAP) NREL/TP-510-42630. (2008).

14. Miller, G. L., Use of dinitrosalicylic acid reagent for determination of reducing sugar. Anal. Chem., 31(3): 426-428 (1959).

15. Hermiati, E., Rekayasa proses hidrolisis ampas tapioka menggunakan pemanasan gelombang mikro untuk produksi etanol. Institut Pertanian Bogor, (2012).

16. Liu, Y., Xu, J., Zhang, Y., He, M., Liang, C., Yuan, Z., \& Xie, J., Improved ethanol production based on high solids fed-batch simultaneous saccharification and fermentation with alkali-pretreated sugarcane bagasse. Bioresour., 11(1): 25482556 (2016).

17. Hidayat, M. R., Teknologi pretreatment bahan lignoselulosa dalam proses produksi bioetanol. Biopropal Ind., 4(1): 33-48 (2013).

18. Fatriasari, W., Karimah, A., Falah, F., Anita, S. H., Effect of amphiphilic lignin derivatives (A-LD) surfactant addition on the fermentation process of sorghum bagasse kraft pulp for bioethanol production. in The IOP Conference Series: Earth and Environmental Science (EES), 591, 12002 (2020).

19. Eriksson, T., Börjesson, J. \& Tjerneld, F., Mechanism of surfactant effect in enzymatic hydrolysis of lignocellulose. Enzyme Microb. Technol., 31(3): 353-364 (2002).

20. Fatriasari, W., Nugroho Adi, D. T., Laksana, R. P. B., Fajriutami, T., Raniya, R., Ghozali, M., \& Hermiati, E., The effect of amphipilic lignin derivatives addition on enzymatic hydrolysis performance of kraft pulp from sorghum bagasse. in IOP Conference Series: Earth and Environmental Science, 141(1) (2018).

21. Fatriasari, W., Nurhamzah, F., Raniya, R., Laksana, R.P.B., Anita, S.H., Iswanto, A.H., 
Hermiati, E., Enzymatic Hydrolysis Performance of Biomass by Addition of Lignin Based Biosurfactant. J. Korean Wood Sci. Technol., 48(5): 651-665 (2020).

22. Fatriasari, W., Hamzah, F. N., Pratomo, B. I., Fajriutami, T., Ermawar, R. A., Falah, F., Laksana, R. P. B., Ghozali, M., Iswanto, A. H., Hermiati, E., \& Winarni, I., Optimizing the Synthesis of Lignin Derivatives from Acacia mangium to Improve the Enzymatic Hydrolysis of Kraft Pulp Sorghum Bagasse. Int. J. Renew. Energy Dev., 9(2): 227-235 (2020).

23. Winarni, I., Koda, K., Waluyo, T.K., Pari, G., Uraki, Y., Enzymatic saccarification of soda pulp from sago starch waste using sago lignin-based amphipatic derivatives. $J$. Wood Chem. Technol., 34(3): 157-168 (2014).

24. Uraki, Y, Koda, K, Yamada, T, Oikawa. C, Aso, T., in ACS Symposium Series Book, 243254. (2012).
25. Wei, L., Shrestha, A., Tu, M. \& Adhikari, S., Effects of surfactant on biochemical and hydrothermal conversion of softwood hemicellulose to ethanol and furan derivatives. Process Biochem., 46(9): 17851792 (2011).

26. Liu, J., Shi, J., Li, J., Yuan, X., \& Liu, C., Effect of surfactant on ethanol production from rice straw by simultaneous saccharification and fermentation. in International Conference on Electronics, Communications and Control (ICECC), (2011).

27. Lee, W.G., Lee, J.S., Lee, J.P., Shin, C.S., Kim, M.S., \& Park, S. C., Effect of surfactant on ethanol fermentation using glucose and cellulosic hydrolyzates. Biotechnol. Lett., 18(3): 299-304 (1996).

28. Laouar, L., Muligan, B. J. \& Lowe, K. C., Yeast permeabilization with surfactants. Biotechnol. Lett., 14(8): 719-720 (1992). 